\section{REPORT OF A LARGE LONGICORN BEETLE ACANTHOPHORUS SERRATICORNIS FROM PUNE, MAHARASTRA}

\section{H.V. Ghate, Milind Gambhir and Nilesh Rane}

Department of Zoology, Modern College, Pune, Maharashtra 411005, India.

Acanthophorus serraticornis (Oliv.) the largest beetle known from India was collected in Pune recently. The beetle was identified with the help of the Fauna of British India volume on "Cerambycidae" (Gahan, 1906). Detailed morphological features of the insect are given by Gahan (1906) hence, not reiterated here. Some pertinent observations and morphometrical data given as only length and breadth are provided by Gahan (1906) in which the beetles are said to be variable in size and that the length varies from 53 to $92 \mathrm{~mm}$ and breadth from 17 to $28 \mathrm{~mm}$. The males are said to be larger, and with more powerful mandibles, than females. Some males are however of the same size as that of the females.

The beetle was previously recorded from Madras, Mysore and Trivandrum (Gahan, 1906). Both Stebbing (1914) and Beeson (1941) have given a few additional comments on this species. Beeson (1941) gives a list of host plants (Bombax malabaricum, Mangifera indica, Morus alba and Shorea robusta) affected and also mentions that "larvae feed on decaying roots of large trees and at intervals leave the wood and travel through the soil alongside... when fully formed, it constructs a large oval cell of earth and fibers of wood,....in which it passes the cold weather...pupating about April...beetles are on the wing in April to September". However, according to Stebbing (1914), in Chota Nagpur, the insects are on wing in June...egg laying is probably around July-August ...grubs feed in the tree throughout the remaining period from July onwards'. In Pune also the $A$. serraticornis was collected in June. Unfortunately, the host plant in Pune is unknown.

The authors are not aware of any subsequent published record, either from Maharashtra or from any other part of India, hence this report. According to Gahan (1906) there are two more species of Acanthophorus, namely A. rugiceps and A. modicus; the former is doubtfully recorded from Bombay (Presidency?) while the latter is known from Lahore.

\section{Acanthophorus serraticornis (Oliv.)}

Material examined

Male, vi.2002, Bhugaon (on Pune-Paud Road), Pune, Maharashtra, coll. Milind Gambhir, Zoology Department, Modern College.

\section{Diagnostic features}

Total length (including mandibles): $115 \mathrm{~mm}$. Mandibles: $21.0 \mathrm{~mm}$, longer than head, ventrally flat, laterally somewhat compressed and with a distinct dorsal carina, left mandible larger than right, right mandible with three teeth (proximal two large and close to each other than the distal) and left mandible with two teeth. Mandibular surface with fine punctures. Tuft of hairs at the base of mandible on either side of the midline.

Head length (at the base of the mandible): $15.5 \mathrm{~mm}$. Head breadth at the level of the eyes: $18.0 \mathrm{~mm}$. Behind the eye region, head more closely punctured and with large number of tawny hairs. Eyes large, vertically elongate, seen from dorsal as well as from the ventral side with prominent supra-orbital ridge.

Antennae 12 jointed, inserted in front of the eye, with first two basal joints lighter, first four joints more rough due to punctures, remaining joints smooth. First antennal joint stout, $4.5 \mathrm{~mm}$ long, rest joints slender. Each antennal joint, from second joint onwards, with an apical spinelike or dentiform process on the outer side. These processes become progressively longer until seventh joint, $12^{\text {th }}$ joint without a spine (total length of antenna: approx. $69 \mathrm{~mm}$ ). The area of the head, between the eyes and the antennae, shining and with a deep longitudinal sulcus. Pronotum transverse, $11.0 \mathrm{~mm}$ long, $26.5 \mathrm{~mm}$ wide (at the tip of longest prothoracic spine), with tawny or reddish-brown hairs on the anterior and posterior borders. These hairs horizontally extend towards head. Mid dorsal area shining, and with few punctures, while the lateral area with many punctures and hairs extending to the dorso-lateral region. Lateral border with three spines with the middle spine the longest. Scutellum tongue-shaped, closely punctured, with slight median depression. Basal half of the scutellum covered with yellow brown hairs. Elytra very long, overall dull and leathery in appearance, colour deep brown. Elytral breadth, at humeral angles, $27 \mathrm{~mm}$. Maximum width of the body (in the middle): $30.0 \mathrm{~mm}$, thereafter gradually decreasing. Individual elytra-maximumbreadth: $15 \mathrm{~mm}$, maximumlength: $61 \mathrm{~mm}$ (from the base of the scutellum to the apex).

Legs - fore and mid femur: $18.5 \mathrm{~mm}$, hind femur: $21.0 \mathrm{~mm}$. Fore tibiae (to the tip of the spine, ventrally): $20.0 \mathrm{~mm}$, mid tibiae: $20.5 \mathrm{~mm}$ and hind tibiae: $24.0 \mathrm{~mm}$. Each tibia with two internal apical spines. Fore tarsus with claw: $12.5 \mathrm{~mm}$; mid tarsus with claw: $13.0 \mathrm{~mm}$; hind tarsus with claw: $14.0 \mathrm{~mm}$. All leg segments with fine punctures and silvery in appearance.

Five abdominal segments visible from the ventral side. Sparse hairs on the abdominal segments. Terminal abdominal segment as well as the lateral side of all sterna covered with thick brown hairs.

\section{Acknowledgements}

Authorities of Modern College for facilities and encouragement.

\section{References}

Beeson, C.F.C. (1941). The Ecology and Control of the Forest Insects of India and Neighbouring Countries. Government of India (1961 reprint), 767pp.

Gahan, C.J. (1906). Fauna of British India, Coleoptera Vol. I(Cerambycidae). Taylor and Francis, London, 329pp.

Stebbing, E.P. (1914). Indian Forest Insects of Economic Importance, Coleoptera. H.M. Secretary of the State for Indian Council. Originally Printed by Eyre and Spottiswoode, London (Indian reprint by Bishen Singh and Mahendra Pal Singh, Dehra Dun), 648pp. 